\title{
Distribution of Fluoride Content in the Water System around Haldiati-Doboka Areas, Assam
}

\author{
U. Tamuly ${ }^{1}$, P. Kotoky ${ }^{2}$, KG. Bhattacharyya ${ }^{3}$ \\ ${ }^{1}$ Department of Chemistry,Namrup College, Parbatpur - 786623, Dibrugarh, Assam, India \\ ${ }^{2}$ Chief Scientist (Rtd.) CSIR-NEIST, Jorhat 785006, Assam, India \\ ${ }^{3}$ Department of Chemistry, Gauhati University, Guwahati 781014, Assam, India
}

\begin{abstract}
The severity of the impending crisis of potable fresh water and contamination to this life sustaining process by fluoride and arsenic is now a critical concern for the NE-India. Both skeletal and dental fluorosis is reported from the Karbi Anglong and Nowgaon districts of Assam with area and population are 10,526 $\mathrm{km}^{2}$ and 700,000 respectively. Considering all these an attempt has been made to understand the distribution pattern of fluoride content in the water resources of Karbi Anglong and adjoining Naogaon districts of Assam. The fluoride content in the water samples of the Haldiati-Doboka areas of the Karbi Anglong district, Assam, varies from $0.05 \mathrm{mg} / \mathrm{L}$ to $3.52 \mathrm{mg} / \mathrm{L}$ with an average of $1.89 \mathrm{mg} / \mathrm{L}$. The study has attributed enough evidence that the water system of the area is not environmentally safe with reference to fluoride content. The arsenic content varies from $3.20-10.60 \mu \mathrm{g} / \mathrm{L}$ (permissible limit of arsenic is $10 \mu g / L ; W H O, 1984)$. Therefore, it can clearly be attributed that the area needs an in-depth investigation in view of the environmental aspects towards improving the quality of life forms around. It is believed that the generated environmental knowledgebase with precision and accuracy will fill up a critical domain in improving the quality of life and people around.
\end{abstract}

Keywords: Fluoride, Water, Haldiati-Doboka, Karbi Anglong, Assam

\section{Introduction}

Impending crisis of potable fresh water and contamination to this life sustaining attributes is a threat to entire life forms on this mother earth. At least, 170 million people in different urban areas of the world still lack a source of portable water near their homes, and in rural areas, although access has increased rapidly in the past decade, more than 855 million people are still without safe drinking water (Barrot, 1998). Many of the states of Indian union already have alarming quantities of arsenic and fluoride in their water resources above their permissible limit to human beings (Susheela, 2007). Within the limitation of available studies so far conducted have shown enough evidences that the environmental segments in North Eastern region of India specifically Assam with respect to water quality of the region is not at all satisfactory (RGNDWM, 1993; Paul, 2000; Chakravarty et al., 2000) . The severity of the problem with respect to fluoride and arsenic is now a critical concern. Both skeletal and dental fluorosis is reported from the Karbi Anglong and Nowgaon districts of Assam with area and population are $10,526 \mathrm{~km}^{2}$ and 700,000 respectively. Available evidence has revealed that one tenth of total population is suffering from fluorosis, which finally leads to paralysis (Kotoky et al., 2008). A group of workers reported presence of fluoride up to $6.88 \mathrm{ppm}$ in drinking water samples of various parts of Guwahati and suburbs (Das, 2000; Das et al., 2003).

Considering all these an attempt has been made to understand the distribution pattern of fluoride content in the water resources of Karbi Anglong and adjoining Naogaon districts of Assam. It is believed that the environmental knowledgebase with precision and accuracy is a critical domain in improving the quality of life and people around.

\section{Methodology}

Thirty four number of water samples from tube well (TW), deep tube well (DTW) and surface water (pond) were collected from Haldiati-Doboka area, Karbi Anglong and adjoining Naogaon Districts, Assam (Figure 1) and analyzed for associated fluoride content utilizing Fluoride Ion Meter. A few representative samples were also utilized for determination of trace element concentrations in them through atomic absorption spectrophotometer (AAS). For both the approaches established standard methodology (APHA, 1995) have been followed to generate precision based knowledgebase and utilized for interpretative use of the present study.

\section{Results and Discussion}

The fluoride content in the studied samples varies from $0.05 \mathrm{mg} / \mathrm{L}$ to $3.52 \mathrm{mg} / \mathrm{L}$ with an average of $1.89 \mathrm{mg} / \mathrm{L}$ (Table 1 ). The study has attributed enough evidence that the deep tube well samples contain comparatively more fluoride content than the hand tube wells. However, the surface water samples have shown less fluoride content below the tolerance limit (WHO, 1984; IS, 1983). Water with high fluoride content, being highly electronegative is preferentially attracted to $\mathrm{ca}^{++}$ions, rich in bones and teeth and is thus deposited as calcium fluoroapatite crystals. However in general fluoride ions from the minerals (fluorospar, fluoroapatite, and cryolite) leach into the ground water and contribute to high fluoride concentrations. Mica group of minerals also occasionally contribute to water fluoride content. The minerals usually fluorospar occurs in structurally weak planes like shear fractures, joints and at the contact of host rock and vein minerals such as vein quartz. They weather and form calcium and magnesium carbonates which act as sink of high fluoride ions. It is the 


\section{International Journal of Science and Research (IJSR) \\ ISSN (Online): 2319-7064 \\ Index Copernicus Value (2013): 6.14 | Impact Factor (2015): 6.391}

leachable state of fluoride ions that determine the water fluoride levels. However, the leachability is governed by 1)
$\mathrm{pH}$ of the draining solution and 2) by the amount of dissolved carbon dioxide in the rock-soil system.

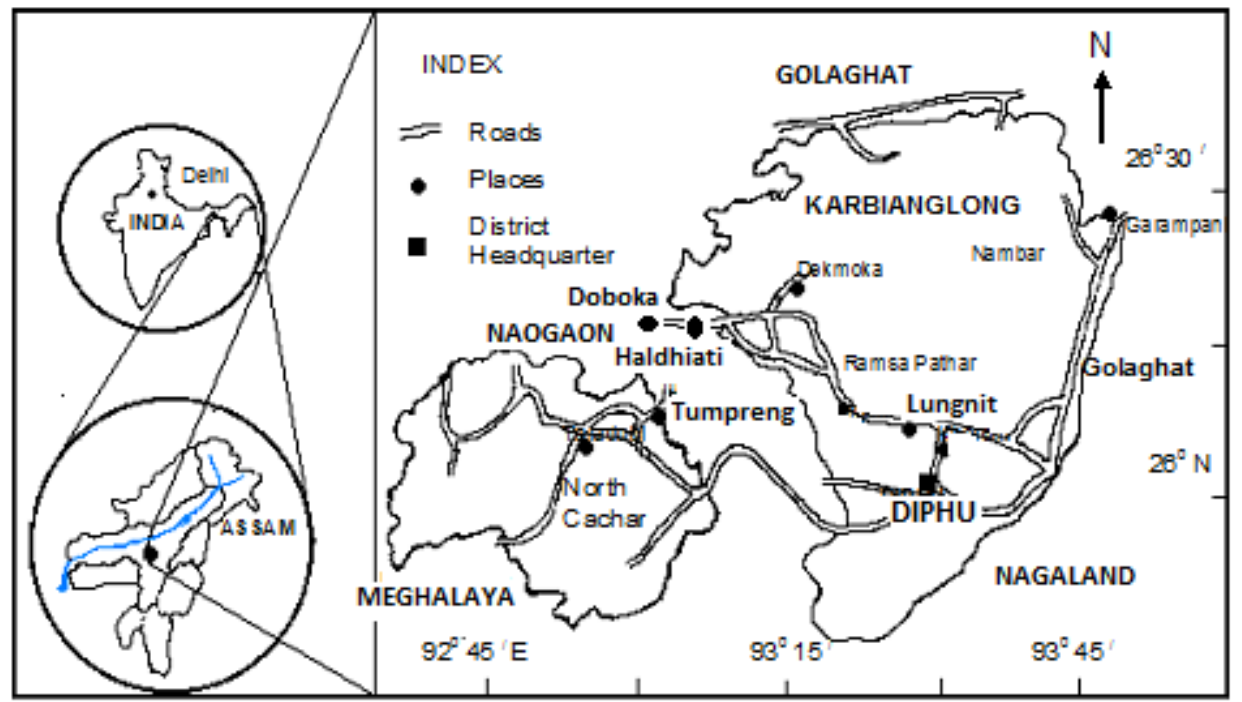

Figure 1: Location map of the study area

Geologically, Karbi Anglong area is highly enriched with mineral matter like limestone and coal. The present observation on the trace element distribution and fluoride content has given strong evidence on the relationship of the fluoride with $\mathrm{Ca}^{2+}$ and $\mathrm{Na}^{+}$contents. The limestone of the region contains the equivalent of 31 to $52 \% \mathrm{CaO}$ and 0.06 to $0.28 \%$ of $\mathrm{Na}$. The strong affinity of $\mathrm{F}^{-}$with $\mathrm{Ca}^{2+}$ and $\mathrm{Na}^{+}$has shown enough evidence towards its association with them and can be considered very well that the existing lithogeological environment has played a major role in distribution of fluoride content in the associated water system. Since the area is free from all types of industrial activities, natural incorporation of fluoride into the water sources is the most plausible explanation for the elevated level of fluoride in them.

Table 1: Concentration of fluoride in water samples around

\begin{tabular}{|c|c|c|c|}
\hline S. No & Locations & Source & $\begin{array}{c}\text { Fluoride } \\
(\mathrm{mg} / \mathrm{L})\end{array}$ \\
\hline 1 & Howraghat (Near Jamuna Nadi Bridge) & DTW & 0.26 \\
\hline 2 & $\begin{array}{c}\text { Howraghat(Near Netaji welfare } \\
\text { Society) }\end{array}$ & DTW & 0.28 \\
\hline 3 & Debasthan & DTW & 0.32 \\
\hline 4 & Nazrana Hotel & HTW & 0.41 \\
\hline 5 & Nilbagan Tiniali & DTW & 0.49 \\
\hline 6 & Udhaganga & $\begin{array}{c}\text { Surface } \\
\text { Water }\end{array}$ & 0.07 \\
\hline 7 & Ardangengti Gaon & HTW & 0.05 \\
\hline 8 & Haldhiati Gaon & DTW & 1.50 \\
\hline 9 & Akashiganga(Near No2 Haldhiati & DTW & 2.90 \\
\hline 10 & Gaon) & DTW & 0.27 \\
\hline 11 & Mahamaya Hotel & HTW & 3.27 \\
\hline 12 & Matikhola & HTW & 2.17 \\
\hline 13 & Nilbagan L.P. School(Two Nos) & HTW & 2.65 \\
\hline 14 & Nilbagan Bazar & HTW & 2.67 \\
\hline
\end{tabular}

\begin{tabular}{|l|c|c|c|}
\hline 15 & Nilbagan Play Field & HTW & 2.35 \\
\hline 16 & Nilbagan M.V. School & HTW & 1.65 \\
\hline 17 & Dakhin Nilbagan & HTW & 2.65 \\
\hline 18 & Jayanti L.P. School & HTW & 2.75 \\
\hline 19 & H. S. School, Doboka & HTW & 0.87 \\
\hline 20 & Namghar, Doboka & HTW & 1.16 \\
\hline 21 & Nizparakhowa & DTW & 3.21 \\
\hline 22 & Udhab Gaon & HTW & 3.12 \\
\hline 23 & Haldhiati (Near L.P.School) & HTW & 3.48 \\
\hline 24 & Pub Nilbagan & HTW & 1.75 \\
\hline 25 & Akashiganga L.P.School & HTW & 1.68 \\
\hline 26 & Engtigaon & DTW & 2.19 \\
\hline 27 & Udhaganga & HTW & 1.64 \\
\hline 28 & Near Jamiuna Nadi & HTW & 2.71 \\
\hline 29 & Haldhiati Tiniali & HTW & 3.52 \\
\hline 30 & Haldhiati (NO.2) & HTW & 3.36 \\
\hline 31 & Doboka & DTW & 3.36 \\
\hline 32 & Doboka H.S. School & HTW & 1.25 \\
\hline 33 & Ragibis House, Doboka & HTW & 2.63 \\
\hline 34 & M.V.School, Nizparakhowa & HTW & 1.69 \\
\hline
\end{tabular}

(DTW=Deep Tube Well; HTW=Hand Tube Well; $R W=$ Ring Well)

\section{Haldiati-Doboka, Kari Anglong-Nowgaon Districts, Assam}

The arsenic content varies from 3.20-10.60 $\mu \mathrm{g} / \mathrm{L}$ (Table 2). Permissible limit of arsenic is $10 \mu \mathrm{g} / \mathrm{L}$ (WHO, 1984). Therefore, it can clearly be attributed that the area needs an in-depth investigation in view of the environmental aspects. The arsenic concentration has shown significant correlation with the iron content. It is believed that the distribution of arsenic is basically related with the associated iron content in them. The higher incorporation of iron to the water system from the associated lithology of the region might have played a role in its distribution and association of arsenic above the permissible limit $(10 \mu \mathrm{g} / \mathrm{L})$. 


\section{International Journal of Science and Research (IJSR) \\ ISSN (Online): 2319-7064 \\ Index Copernicus Value (2013): 6.14 | Impact Factor (2015): 6.391}

Table 2: Elemental Concentration of the water samples (As * $\mu \mathrm{g} / \mathrm{L}$ and others are in $\mathrm{mg} / \mathrm{L}$ )in and around Hadiati-Doboka area, Karbi Anglong District, Assam

\begin{tabular}{|c|c|c|c|c|c|c|c|c|c|c|c|c|c|c|c|}
\hline Sl. No. & $F$ & $M g$ & $\mathrm{Zn}$ & $\mathrm{Na}$ & $\mathrm{K}$ & $\mathrm{Ca}$ & $\mathrm{Pb}$ & $\mathrm{Fe}$ & $\mathrm{Mn}$ & $\mathrm{Ni}$ & $\mathrm{Cd}$ & $\mathrm{Cr}$ & $\mathrm{Co}$ & $\mathrm{Cu}$ & $A s^{*}$ \\
\hline 1 & 0.26 & 61.5 & 0.14 & 171 & 46.9 & 45.2 & BDL & 1.49 & 0.16 & BDL & 0.04 & BDL & BDL & BDL & 4.3 \\
\hline 2 & 0.26 & 46.7 & 0.46 & 201 & 16.9 & 48.7 & BDL & 2.12 & 0.22 & BDL & 0.06 & BDL & BDL & 0.09 & 7.8 \\
\hline 3 & 0.31 & 65.8 & 0.09 & 214 & 15.1 & 55.0 & BDL & 0.38 & BDL & BDL & BDL & BDL & BDL & BDL & 3.9 \\
\hline 4 & 0.41 & 54.6 & 0.14 & 310 & 24.6 & 51.9 & BDL & 2.52 & BDL & BDL & 0.08 & BDL & BDL & BDL & 10.2 \\
\hline 5 & 0.49 & 30.7 & 0.13 & 420 & 22.5 & 63.4 & BDL & BDL & BDL & BDL & BDL & BDL & BDL & BDL & 4.1 \\
\hline 6 & 0.07 & 5.9 & 0.17 & 186 & 15.7 & 32.6 & BDL & 0.53 & 0.27 & BDL & 0.03 & BDL & BDL & BDL & 3.2 \\
\hline 8 & 0.05 & 12.3 & 0.11 & 253 & 37.9 & 34.5 & BDL & BDL & 0.13 & BDL & BDL & BDL & BDL & BDL & BDL \\
\hline 9 & 1.47 & 25.4 & 0.25 & 790 & 19.9 & 81.5 & BDL & 1.84 & 0.47 & BDL & BDL & BDL & BDL & BDL & 9.5 \\
\hline 10 & 2.89 & 20 & 0.4 & 853 & 24.6 & 87.0 & BDL & 2.96 & 0.05 & BDL & 0.04 & BDL & BDL & BDL & 10.6 \\
\hline 11 & 0.27 & 2.6 & 0.11 & 183 & 46.1 & 19.8 & BDL & BDL & BDL & BDL & BDL & BDL & BDL & BDL & BDL \\
\hline
\end{tabular}

The scenario as evidenced from the study along with the available literature is alarming enough and a concerted effort combining all the related aspects towards understanding the root cause of the problem is an utmost requirement (Tamuli, 2010; Kotoky et al., 2010). It can very well be attributed from the study that the area is not evenly affected by the fluoride content in the water system. The areas having more than $1.5 \mathrm{mg} / \mathrm{L}$ of fluoride concentration needs specific attention to undertake detail investigation combining human health and societal implications. The part played by the local geology of the areas around needs in-depth investigation with detail identification/transformation/dissolution/ leaching mechanism of fluoride containing minerals in them. The fluoride content as evidenced from the study is increasing with the increase in deepness of bore well. Therefore, as an alternative source, development of system for water supply from natural sources like river (as is presently carried out by Gujarat Government) can be a most effective solution. As it is generally seen that complaints of skeletal joint pain and dental fluorosis is increasing rapidly with urbanization of human society all water supply system should invariably be monitored and studied before it reaches hands of common people.

\section{Conclusion}

The fluoride content in the water samples of the HaldiatiDoboka areas of the Karbi Anglong district, Assam, varies from $0.05 \mathrm{mg} / \mathrm{L}$ to $3.52 \mathrm{mg} / \mathrm{L}$ with an average of $1.89 \mathrm{mg} / \mathrm{L}$. The study has attributed enough evidence that the water system of the area is not environmentally safe with reference to fluoride content. The deep tube well samples contain comparatively more fluoride content than the hand tube wells and surface water source is comparatively free. Moreover, analysis of trace element concentration has attributed a notable observation that the water system of the area is not only contaminated by fluoride content but also associated with arsenic content above the prescribed tolerance limit. The arsenic content varies from 3.20$10.60 \mu \mathrm{g} / \mathrm{L}$ (permissible limit of arsenic is $10 \mu \mathrm{g} / \mathrm{L}$; WHO, 1984). Therefore, it can clearly be attributed that the area needs an in-depth investigation in view of the environmental aspects towards improving the quality of life forms around.

\section{Acknowledgement}

The author (UT) is grateful to Dr PG Rao, Director, North East Institute of Science and Technology (CSIR), Jorhat,
Assam, India, for his kind permission and constant inspiration.

\section{References}

[1] A.P, H.A., (1995) Standard methods for the examination of water and waste water, 19th. Edition,

[2] Barrot, VV. (1998) Fluoride contamination its health hazard and defluoridisation of water, Environmental Pollution Control Journal, 67-69.

[3] Chakravarti, D., Chanda, CR., Samanta, G., Chowdhury, UK., Mukherjee, SC., Pal, AB., Sharma, B., Mahanta, KJ., Ahmed, HA. and Sing, B.(2000) Fluorosis in Assam,India, Cur. Sci., 78, 1421-1423.

[4] Das, N. N. (2000) Fluoride and drinking water of Karbianglong district (In Assamese), Parivesh Batori (Environmental Bulletin), Pollution control Board, Assam, X, No. 3, 15.

[5] Das, B., Talukdar, J., Sarma, S., Gohain, B., Dutta, RK., Das, HB., and Das, SC. (2003) Fluoride and other inorganic constituents in ground water of Guwahati, Assam, Current Science, 85, 657-61.

[6] Indian Standard Specification (IS) (1983) No. IS 105009.

[7] Kotoky, P, Barooah PK., Baruah, MK., Goswami, A, Borah GC., Gogoi, HM., Ahmed, F., Gogoi, A., and Paul, AB. (2008) Fluoride and endemic fluorosis in the Karbi Anglong district, Assam, India. Fluoride 40, 4245.

[8] Kotoky, P., Tamuli, U., Borah, GC., Baruah, MK., Sarmah, BK., Paul, AB., and Bhattacharyya, KG. (2010) A Fluoride Zonation map of the Karbi Anglong district, Assam, India Fluoride 43(2), 113-115.

[9] Kotoky, P. (2011) Geoenvironmental Perspectives, Science and Culture, 77, 474 - 479.

[10] Paul, AB.(2000) Slow poisoning: Fluoride in groundwater of Karbi Anglong district, Souvenir, Assam Public Health Engineering Association.

[11]Rajiv Gandhi National Drinking Water Mission (RGNDWM), (1993) Prevention and control of fluorosis in India, Health Aspects, Vol. I, Ministry of Rural Development, New Delhi, 60.

[12] Susheela AK. A treatise on fluorosis. (2007) 3rd ed. Delhi: Fluorosis Research and Rural Development Foundation.

[13] Tamuly, U., Kotoky, P. and Borah, GC., and Bhattacharyya, KG. (2010) Fluoride a natural

[14] contaminant in the water system of the Karbi Anglong district, Assam, National seminar on "Crisis of fresh 


\section{International Journal of Science and Research (IJSR) \\ ISSN (Online): 2319-7064}

Index Copernicus Value (2013): 6.14 | Impact Factor (2015): 6.391

water, a challenge to humanity and life processes, What is the solution" at D.R. College, Assam, August 17-18, 71-72.

[15] W.H.O. Guidelines for drinking water quality, (1984)

Vol. 1, recommendations- W.H.O., Geneva. 